\title{
Do Better-Connected CEOs Innovate More?
}

\author{
Olubunmi Faleye, Tunde Kovacs, and Anand Venkateswaran*
}

\begin{abstract}
We present evidence suggesting that chief executive officer (CEO) connections facilitate investments in corporate innovation. We find that firms with better-connected CEOs invest more in research and development and receive more and higher quality patents. Further tests suggest that this effect stems from two characteristics of personal networks that alleviate $\mathrm{CEO}$ risk aversion in investment decisions. First, personal connections increase the CEO's access to relevant network information, which encourages innovation by helping to identify, evaluate, and exploit innovative ideas. Second, personal connections provide the CEO with labor market insurance that facilitates investments in risky innovation by mitigating the career concerns inherent in such investments.
\end{abstract}

\section{Introduction}

The importance of corporate innovation in fostering higher firm value is well understood. ${ }^{1}$ Nevertheless, executives differ in their willingness to undertake such investments because cultivating innovation requires significant managerial involvement, nurturing of firm-specific human capital, and potential disruptions in relationships with other stakeholders such as employees, suppliers, and the local community (Jensen (1993)). The payoffs also are highly uncertain and the probability of failure is substantial (Bhagat and Welch (1995), Kothari, Laguerre, and Leone (2002)). In addition, investing in research and development (R\&D) typically depresses concurrent operating income because accounting rules require

*Faleye, o.faleye@neu.edu, Venkateswaran, a.venkateswaran@neu.edu, D’Amore-McKim School of Business, Northeastern University, 360 Huntington Ave, Boston, MA 02115; and Kovacs, tunde_kovacs@uml.edu, Manning School of Business, University of Massachusetts Lowell, 1 University Ave, Lowell, MA 01854. We are grateful to David Denis, Rani Hoitash, Udi Hoitash, Karthik Krishnan, Paul Malatesta (the editor), two anonymous referees, and seminar participants at Northeastern University, Bentley University, University of Arkansas, and the 2012 Financial Management Association Annual Meeting for helpful comments.

${ }^{1}$ For example, Griliches (1986) shows that higher R\&D spending is associated with significant growth in firm-level productivity, and Sougiannis (1994) estimates that an increase of $\$ 1$ in R\&D investments increases long-term profits and market value by $\$ 2$ and $\$ 5$, respectively. Similarly, Chan, Martin, and Kensinger (1990) show that share prices increase when firms announce increased R\&D spending, and Eberhart, Maxwell, and Siddique (2004) report similar effects on long-term abnormal operating performance. Trajtenberg (1990) and Harhoff, Narain, Scherer, and Vopel (1999), among others, report similar value effects for patents and patent citations. 
expensing most R\&D spending as it is incurred. Thus, corporate innovation depends on the willingness of chief executive officers (CEOs) to engage in risky and potentially disruptive projects that have a negative short-term impact on financial performance. In this article, we examine the role of CEO connections in increasing such willingness.

Burt (2004) and McDonald, Khanna, and Westphal (2008) show that personal connections expose the CEO to alternative points of view that enhance the quality of strategic choices in unfamiliar settings. In addition, Schonlau and Singh (2009) and Larcker, So, and Wang (2013) suggest that valuable information percolates through the network of top corporate executives. Thus, well-connected CEOs are able to access network information that improves their ability to identify and exploit innovation opportunities. These information effects can reduce managerial risk aversion in corporate innovation investments by diminishing the ex ante riskiness of innovation projects, thus leading to more and/or higher quality corporate innovation.

Personal connections also can reduce the ex post risk of undertaking innovation investments. A potential loss of employment is perhaps the greatest personal cost borne by the CEO in cases of failed innovation; thus, rational CEOs may prefer routine projects and incremental improvements to drastic innovation with higher probabilities of failure. Network connections can minimize the personal consequences of failure to the $\mathrm{CEO}$ by providing an implicit labor market insurance against job losses. Mazerolle and Singh (2004) show that personal connections improve the odds of re-employment following labor market displacement, and Cingano and Rosolia (2012) show that unemployment duration declines with the quality of a worker's personal network. Thus, a network of friends, acquaintances, and former colleagues can provide a safety net that enhances the likelihood of re-employment should the CEO lose his current job for any reason, including a low tolerance for failed innovation attempts. This minimizes the CEO's exposure to the left-tail risk of corporate innovation without affecting his exposure to the right tail, again leading to more and/or better innovation.

We test our hypothesis on a sample of 2,366 unique CEOs at 1,532 unique Standard \& Poor's (S\&P) 1500 firms over 1997-2006. As in several recent studies, we measure innovation along two dimensions, namely, R\&D spending and patenting activity. Consistent with our hypothesis, we find that corporate innovation increases with CEO connections. An interquartile change in CEO connections is associated with increases of $9.7 \%$ in R\&D investment rate, $11 \%$ in patents granted by the U.S. Patent and Trademark Office (USPTO), and $4 \%$ in citations per patent. We consider several alternative explanations for these effects, including the abilities of CEOs, job-hopping by adventurous CEOs, and the clustering of highly connected CEOs in innovative industries. Our results are robust to these issues. They also are robust to several adjustments for endogeneity concerns, including reverse causality and omitted variable bias.

Next, we evaluate potential channels through which CEO connections facilitate investments in corporate innovation, focusing on the information and employment hedge effects of personal networks. We start with an analysis of the information channel, performing two sets of tests to search for information effects. First, we identify the component of CEO connections most likely to contain 
innovation-relevant information, expecting such component to offer significant explanatory power beyond the impact of total CEO network if information effects are important. Second, we decompose CEO connections into two orthogonal components: the portion that is more likely to transmit innovation information and the portion that is less likely to do so, expecting the former to have a greater effect on corporate innovation under the information channel hypothesis. In both cases, we find results that are consistent with expectations. For the $\mathrm{CEO}$ with a median-sized network, an increase from the first quartile to the third quartile in innovationinformation connections is associated with an increase of $27.6 \%, 17.6 \%$, and $7.9 \%$ in R\&D investment, patents, and citations per patent, respectively. Similarly, an interquartile change in the portion of CEO network more likely to transmit innovation information is associated with increases of $29.3 \%, 22.1 \%$, and $9.5 \%$ in $R \& D$ investment, patents, and citations per patent, respectively, compared to increases of $7.3 \%, 9.2 \%$, and $3.0 \%$ for a similar change in the portion of CEO network less likely to transmit such information.

We also test for labor market insurance effects in two steps. First, we examine the impact of CEO connections on labor market outcomes following forced turnover. We find that the probability of re-employment at the top management level increases with personal connections and that better-connected CEOs are appointed to more corporate boards following forced turnover. Thus, personal connections diminish the adverse effects of a job loss. Second, we examine whether this employment hedge is associated with corporate innovation by analyzing the impact of the likelihood of re-employment following dismissal on the quantity and quality of corporate innovation investments. Using estimated odds from our re-employment prediction models, we find that $R \& D$ investments, patents, and citations per patent increase significantly with the odds that the CEO will secure another top-level job if he were dismissed from his current position.

These results contribute to two distinct literatures. First, we contribute to the literature on the determinants of corporate innovation. Early papers on this topic (e.g., Hall and Ziedonis (2001)) focus on the role of basic firm characteristics. More recent papers (e.g., Atanassov (2013), Faleye, Hoitash, and Hoitash (2011)) consider the effects of internal and external corporate governance mechanisms. We extend this literature by showing that CEO career concerns and access to network information also play significant roles in explaining differences in corporate innovation.

Second, we contribute to the literature on social networks and executive connections. Much of the recent literature in this area suggests that social networks impose agency costs on shareholders. Hwang and Kim (2009) show that social connections between the CEO and directors facilitate higher pay levels, lower pay-performance sensitivity, and lower turnover probability. Fracassi and Tate (2012) report that well-connected CEOs engage in more value-destroying acquisitions and are associated with lower firm value. Ang, Nagel, and Yang (2010) find that well-connected CEOs receive compensation in excess of what is attributable to economic and governance factors, and Kramarz and Thesmar (2007) show that turnover-performance sensitivity declines with CEO and board connections. Our results suggest that these connections can have a positive effect by minimizing potential agency problems in corporate investment choices. Specifically, personal 
connections increase the CEO's willingness to engage in desirable risky innovation by providing valuable information and outside employment opportunities that reduce his risk aversion in corporate investment decisions.

The remainder of the article proceeds as follows: The next section describes the sample and presents descriptive statistics for the main variables. Section III contains our empirical tests and robustness checks, and Section IV explores potential channels through which CEO connections facilitate corporate innovation. Section V concludes.

\section{Sample and Data}

Our sample consists of all firms in the S\&P 1500 indexes. We obtain data on these firms from six sources. Data on CEO characteristics and personal connections come from the BoardEx database, which provides detailed biographical information on directors and top executives of public and private companies as well as not-for-profit organizations. Because BoardEx coverage starts in 1997, our sample also starts in that year. We obtain patent and patent citation data from the National Bureau of Economic Research (NBER) patent database as described in Hall, Jaffe, and Trajtenberg (2001) and updated on Bronwyn Hall's Web site (http://eml.berkeley.edu/ bhhall/patents.html). Patent data end in 2006, which means that our sample also ends in that year. We obtain accounting data from Compustat, CEO compensation data from ExecuComp, board structure data from RiskMetrics' directors database, and golden parachute data from RiskMetrics' takeover defenses database. Our final sample includes all firms in the intersection of these databases, consisting of 9,352 firm-year observations for 2,366 unique CEOs at 1,532 unique firms.

\section{A. Variable Definitions}

\section{Measures of Corporate Innovation}

We measure corporate innovation along two dimensions: R\&D investment and patenting activity. We choose the first because the timing of R\&D expenditures is closest to the initiation of innovation activity and because it is widely used in the literature as a measure of corporate investment in strategic innovation. We define $R \& D$ investment as the ratio of $R \& D$ expenditures to total assets. Following prior studies, we set $R \& D$ investment to 0 when Compustat reports $R \& D$ expenses as missing.

We employ two measures of patenting activity as additional metrics of innovation to sidestep potential limitations of R\&D investment. Atanassov (2013) argues that $\mathrm{R} \& \mathrm{D}$ is principally an input into the innovation process and may not necessarily represent its outcome. Jensen (1993) suggests that higher R\&D can simply reflect managerial spending on pet and/or relatively routine projects rather than significant corporate innovation expenditures. These and other authors recommend patenting activity as a complementary measure of corporate innovation. Our first measure of patenting activity is the number of patents received by each company from the USPTO, and the second is the average number of citations per patent (excluding self-cites). Because the patent database is exhaustive, we set patent variables to 0 for firm-years not represented in the database. We assign 
each patent to its application year (rather than the year the patent is granted) because the timing of innovation is closer to the year in which the company files the patent application. ${ }^{2}$ Furthermore, we correct citations for the truncation bias stemming from the fact that older patents can garner more citations simply because of their longer lives (Hall et al. (2001)).

\section{Measures of CEO Connections}

We measure CEO connections as the total number of individuals with whom the CEO shares a common employment, educational, or social history in the BoardEx universe each year. Two people share a common employment history in a particular year if they were employed at or served on the board of the same company (public or private) before or during that year. Given our objective of examining the effects of CEO connections, there is a concern that the CEO's employment connections might reflect contacts derived from the position itself rather than the CEO's personal connections. To mitigate this concern, we exclude connections derived from the CEO's employment as CEO at his current firm. ${ }^{3}$ For educational connections, we follow Cohen, Frazzini, and Malloy (2008) and require that two individuals attended the same institution, graduated within 2 years of each other, and earned a similar type of degree. We define social connections as connections established via other organizations, such as clubs, charities, sporting, or other not-for-profit organizations. With the exception of social clubs, we require that both individuals' roles exceed mere membership. For about $90 \%$ of noncorporate associations, the starting date of involvement is not reported in BoardEx. To mitigate significant data loss, we assume these connections commenced before the beginning of our sample (i.e., before 1997).

For all connection types, we regard two individuals as connected in all future years once a connection is established between them, which implies that the number of connections generally does not decrease over time. This introduces a mechanical time trend in the network measure, which we correct by removing the time trend from the network variable. Our regression models use the natural log of the detrended variable to minimize the impact of potential outliers. ${ }^{4}$

\footnotetext{
${ }^{2}$ On average, patents are granted 2.1 years after an application is filed. Because our patent data end in 2006 and patents are not reported until granted, it is possible that patent data for the last 2 years of our sample do not accurately reflect patenting activity during those years. We examine the robustness of our results to this issue by estimating regressions restricted to years earlier than 2004. Our results remain unchanged.

${ }^{3}$ For example, W. James McNerney Jr. (Chairman/CEO, Boeing) is connected to every Boeing director and executive simply because he is $\mathrm{CEO}$ of Boeing. We exclude those connections because they derive from his position as Boeing's CEO. At the same time, Mr. McNerney is connected to directors on the boards of P\&G and IBM because he serves on those boards. We include those connections because they are not derived from his position as Boeing's CEO. Our results also hold without this adjustment.

${ }^{4}$ Specifically, we first regress the raw count of contacts on a time trend. Next, we calculate our network variable as the natural log of 1 plus the sum of the residual and the absolute value of its sample minimum. Addition of the constant (absolute value of sample minimum residual plus 1) to all residuals ensures that the log-transformed variable is defined for all observations with valid untransformed values. This approach follows Kale, Reis, and Venkateswaran (2009). As demonstrated in Section III.B.6, our results remain the same if we use the actual count of contacts as the measure of CEO connections.
} 


\section{Control Variables}

We control for several firm and managerial characteristics that prior work suggests as important covariates of corporate innovation. Hall and Ziedonis (2001) and Atanassov (2013) argue that larger firms innovate more because they enjoy information advantages as well as economies of scale and scope in R\&D and the patenting process. In contrast, Brown, Fazzari, and Petersen (2009) and Faleye et al. (2011) argue that financial leverage constrains innovation by increasing managerial risk aversion and diminishing resources available for risky long-term projects. They also suggest that growth options facilitate innovation because managers may need to innovate to exploit those opportunities. Therefore, we control for firm size, leverage, and growth opportunities. We measure firm size as the natural $\log$ of total assets, leverage as the ratio of long-term debt (including current maturities) to total assets, and growth opportunities using market/book ratio, calculated as the book value of total assets minus the book value of equity plus the market value of equity, divided by the book value of total assets.

Manso (2011) analyzes a model that shows that the optimal incentive scheme for stimulating corporate innovation involves a significant tolerance for early failure and reward for long-term success. Consistent with this, Francis, Hasan, and Sharma (2011) find a positive association between corporate innovation and CEO golden parachutes as well as option grants. To account for these effects, our regressions include the delta and vega of the CEO's option and equity holdings as well as an indicator variable that equals 1 for firms with golden parachutes, and 0 otherwise. In addition, we control for CEO age and tenure because Bushee (1998) shows that CEOs exhibit greater myopia as they near retirement. We include the squared terms of age and tenure to capture the nonlinearity in the effects of these two variables on corporate innovation.

Furthermore, we include an indicator variable for founder CEOs because Puri and Robinson (2013) show that entrepreneurs are more optimistic and exhibit a higher preference for risk taking. We also control for staggered board elections because Faleye (2009) and Sapra, Subramanian, and Subramanian (2014) show that investments in corporate innovation are significantly affected by antitakeover provisions. Finally, we control for operating profitability and CEO duality as in Faleye (2009). We measure operating profitability as the ratio of income before extraordinary items to total assets, and staggered board elections and CEO duality using indicator variables that equal 1 when directors are elected to staggered terms and when the CEO also serves as board chair, respectively, and 0 otherwise. We winsorize all nonbinary variables at the 1st and 99th percentiles to minimize the effects of potential outliers. The Appendix contains a list of all variables and their definitions.

\section{B. Descriptive Statistics}

Table 1 presents descriptive statistics for the previously described variables. The table shows that our sample firms are fairly large, with mean and median total assets of $\$ 5.8$ billion and $\$ 1.7$ billion, respectively. As in several prior studies, the median is 0 for each measure of corporate innovation, suggesting that the typical firm in our sample does not engage in technical or patentable innovation. 
TABLE 1

Descriptive Statistics

The sample consists of 9,352 firm-year observations for 2,366 unique firms over 1997-2006. Firm size is total assets in millions of dollars. R\&D is the ratio of research and development expenditures to total assets. Patents is the number of patent applications eventually granted. Patent cites is average citations per patent, excluding self-cites. CEO age is chief executive officer age measured in years. CEO tenure is the number of years for which the CEO has been in office. CEO connections is the number of individuals with whom the CEO shares a common educational, employment, or social history in BoardEx, excluding individuals connected to him solely via his position as CEO of his own firm. Professional connections is the natural log of 1 plus the detrended number of individuals with whom the CEO shares a common employment history in BoardEx. Education connections is the natural log of 1 plus the detrended number of individuals with whom the CEO attended the same school, graduated within 2 years of each other, and earned a similar type of degree. Social connections is the natural log of 1 plus the detrended number of individuals with whom the CEO is connected through social clubs, charities, sporting, or other not-for-profit organizations. CEO delta is $10^{-6}$ times the dollar sensitivity of CEO firm-specific wealth (option and stockholdings) to $1 \%$ change in the firm's stock price. CEO vega is $10^{-6}$ times the dollar sensitivity of CEO firm-specific wealth (option and stockholdings) to 0.01 change in the firm's stock return volatility. Golden parachute equals 1 if the corporation has a golden parachute arrangement in place for the $\mathrm{CEO}$, and 0 otherwise. CEO-chair equals 1 if the CEO also serves as board chair, and 0 otherwise. Founder CEO equals 1 if BoardEx identifies the CEO as a founder or cofounder of the company, and 0 otherwise.

\begin{tabular}{|c|c|c|c|c|c|}
\hline Variables & 25th Pctl. & Mean & Median & 75th Petl. & Std. Dev. \\
\hline Firm size & 674.926 & $5,787.894$ & $1,685.101$ & $5,080.750$ & $11,143.913$ \\
\hline$R \& D$ & 0.000 & 0.029 & 0.000 & 0.037 & 0.049 \\
\hline Patents & 0.000 & 17.765 & 0.000 & 4.000 & 63.623 \\
\hline Patent cites & 0.000 & 2.626 & 0.000 & 1.769 & 6.008 \\
\hline CEO age & 50.000 & 54.749 & 55.000 & 59.000 & 7.181 \\
\hline CEO tenure & 6.000 & 9.602 & 8.000 & 12.000 & 6.083 \\
\hline CEO connections & 36.000 & 174.354 & 103.000 & 245.000 & 197.825 \\
\hline Professional connections & 35.000 & 144.895 & 79.000 & 180.000 & 175.499 \\
\hline Education connections & 1.000 & 26.076 & 12.000 & 36.000 & 36.487 \\
\hline Social connections & 0.000 & 32.590 & 2.000 & 35.000 & 64.225 \\
\hline CEO delta & 0.074 & 0.807 & 0.222 & 0.631 & 2.060 \\
\hline CEO vega & 0.005 & 0.140 & 0.048 & 0.154 & 0.249 \\
\hline Golden parachute & 0.000 & 0.657 & 1.000 & 1.000 & 0.475 \\
\hline CEO-chair & 0.000 & 0.662 & 1.000 & 1.000 & 0.473 \\
\hline Founder CEO & 0.000 & 0.109 & 0.000 & 0.000 & 0.312 \\
\hline
\end{tabular}

In contrast, means are positive and significant, with average $\mathrm{R} \& \mathrm{D}$ investment rate, patents per year, and citations per patent of $2.9 \%, 18$, and 2.6 , respectively.

Table 1 shows further that the average CEO is 55 years old, has been CEO for 9.6 years, and is connected to 174 individuals. Of these, 145 are people he knows through prior employment, 26 through shared educational histories, and 33 through membership in the same social, cultural, and/or not-for-profit organizations..$^{5}$ Median CEO age, tenure, and total connections are 55 years, 8 years, and 103, respectively. Mean and median values of CEO option delta are 0.81 and 0.22 , and mean and median vega values are 0.14 and 0.05 , respectively. Sixty-six percent of CEOs are covered by golden parachute severance agreements, $66 \%$ serve as board chairs, and $11 \%$ are classified by BoardEx as founders or cofounders of their firms.

\section{Empirical Analysis and Results}

\section{A. CEO Connections and Corporate Innovation}

First, we divide the sample into quartiles on the basis of total CEO connections. Mean and median (untransformed) total connections for the first through fourth quartiles are 14 and 13, 66 and 65, 162 and 156, and 455 and 397,

\footnotetext{
${ }^{5}$ The sum is greater than 174 because some individuals are connected to the CEO through more than one shared background.
} 
respectively. Next, we perform univariate comparisons of our measures of corporate innovation across the four groups (untabulated). We find that mean R\&D investment rate increases from $2.4 \%$ of total assets for the first quartile to $2.4 \%$, $2.9 \%$, and $3.9 \%$ for the second, third, and fourth quartiles, respectively. Similarly, mean patents and citations per patent increase from 4.8 and 2.5 for the first quartile to 45 and 3.4 for the fourth quartile. We observe similar patterns in the distribution of medians, and both the $F$-test (corrected for CEO-level clustering) and the Wilcoxon rank-sum test indicate that the means and medians are significantly different at the $1 \%$ level. Thus, the univariate analysis suggests that larger CEO networks are associated with more and higher quality corporate innovation.

Next, we estimate regressions of corporate innovation on CEO connections, controlling for the variables described in Section II.A.3. The dependent variable in the first regression is the ratio of $R \& D$ expenditures to total assets, and the second and third regressions use the natural $\log$ of 1 plus the number of ultimately granted patents applied for during the year and the natural log of 1 plus non-self-citations per patent, respectively. Because true innovation is not observable for firm-years with 0 values on the dependent variables, we estimate each regression as a Tobit model. We also include year fixed effects to control for common fluctuations in innovation activity over time, and Fama and French's (1997) 48 industry fixed effects to control for industry differences in the level of innovation. Finally, we correct standard errors for CEO-level clustering. Results are summarized in Table 2.

The first column of Table 2 shows that better-connected CEOs invest more in R\&D. The coefficient of CEO connections is 0.007 , which is significant at the $1 \%$ level. Note that because the regression is a Tobit model, the marginal effect of each variable on observed $R \& D$ does not equal its regression coefficient. The estimated marginal effect of a 1-unit change in CEO connections on R\&D is 0.002 when other variables are evaluated at their sample means, whereas a change from the first quartile to the third quartile of CEO connections represents 1.412 units. Thus, a firm whose CEO is at the third quartile on personal connections invests an additional $0.28 \%$ of its assets in R\&D compared to a firm whose CEO is at the first quartile, holding all else equal. Because the unconditional mean for R\&D expenditures is $2.9 \%$ of total assets, this represents an increase of $9.7 \%$, which is an economically significant increase in corporate innovation investments.

The second and third columns of Table 2 show similar results for patents and citations per patent. In the second column, the coefficient of CEO connections is 0.187, which implies that a third-quartile company in terms of CEO connections applies for and ultimately receives $11 \%$ more patents relative to a first-quartile company, even after controlling for the level of R\&D investment. Similarly, the third column implies that an interquartile change in CEO connections increases the probability of a cited patent by $10 \%$ and the number of citations per patent by $4 \%$, conditional on being cited.

Results for control variables in Table 2 are similar to those reported in prior studies. Consistent with Bushee (1998), we find that corporate investments in $R \& D$ exhibit a concave relation with CEO age. We also find that $R \& D$ investment is higher when the CEO is covered by a golden parachute and increases with the vega of outstanding CEO stock options, which is consistent with Manso (2011) 
and Francis et al. (2011). Table 2 further shows that R\&D spending, firm size, and growth opportunities are each positively associated with patent quantity and quality, whereas leverage has a negative effect. These results are consistent with previous studies such as Hall and Ziedonis (2001), Atanassov (2013), Brown et al. (2009), and Faleye et al. (2011).

TABLE 2

\section{CEO Connections and Corporate Innovation: Basic Results}

The dependent variables are the ratio of research and development (R\&D) expenditures to total assets in the first column and the natural logs of 1 plus patents applications eventually granted and of citations per patent in the second and third columns. CEO connections is the natural log of 1 plus the detrended number of individuals with whom the CEO shares a common educational, employment, or social history in BoardEx. Firm size is the natural log of total assets. Market/book ratio is book value of total assets minus the book value of equity plus the market value of equity, divided by the book value of total assets. Classified board equals 1 if directors are elected to staggered terms, and 0 otherwise. ROA is income before extraordinary items divided by total assets. Leverage is the ratio of long-term debt (including current portion) to total assets. CEO age is the natural log of chief executive officer (CEO) age in years. CEO tenure is the natural log of the number of years for which the CEO has been in office. CEO delta is the natural log of $10^{-6}$ times the dollar sensitivity of CEO firm-specific wealth (option and stockholdings) to $1 \%$ change in the firm's stock price. CEO vega is the natural log of $10^{-6}$ times the dollar sensitivity of CEO firm-specific wealth (option and stockholdings) to 0.01 change in the firm's stock return volatility. Golden parachute equals 1 if the corporation has a golden parachute arrangement in place for the CEO, and 0 otherwise. CEO-chair equals 1 if the CEO also serves as board chair, and 0 otherwise. Founder CEO equals 1 if BoardEx identifies the CEO as a founder or cofounder of the company, and 0 otherwise. Each regression includes year and Fama-French (1997) 48 industry dummies. Test statistics based on robust standard errors clustered at the CEO level are shown in parentheses. ${ }^{* * *},{ }^{* *}$, and ${ }^{*}$ indicate significance at the $1 \%, 5 \%$, and $10 \%$ levels, respectively.

\begin{tabular}{|c|c|c|c|}
\hline Variables & $R \& D$ & Patents & $\underline{\text { Patent Cites }}$ \\
\hline CEO connections & $\begin{array}{l}0.007^{\star \star \star *} \\
(4.50)\end{array}$ & $\begin{array}{l}0.187^{\star \star \star} \\
(3.13)\end{array}$ & $\begin{array}{l}0.122^{* *} \\
(2.34)\end{array}$ \\
\hline Firm size & $\begin{array}{l}-0.004^{\star \star \star} \\
(-3.59)\end{array}$ & $\begin{array}{l}0.842^{\star \star \star} \\
(19.14)\end{array}$ & $\begin{array}{l}0.412^{\text {*** }} \\
(11.07)\end{array}$ \\
\hline Market/book ratio & 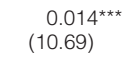 & $\begin{array}{l}0.094^{* \star *} \\
(2.63)\end{array}$ & $\begin{array}{l}0.074^{\star *} \\
(2.24)\end{array}$ \\
\hline Classified board & $\begin{array}{l}-0.006^{\star \star} \\
(-2.24)\end{array}$ & $\begin{array}{c}0.075 \\
(0.79)\end{array}$ & $\begin{array}{c}0.020 \\
(0.25)\end{array}$ \\
\hline $\mathrm{ROA}$ & $\begin{array}{l}-0.180^{\star \star \star} \\
(-10.57)\end{array}$ & $\begin{array}{c}0.545 \\
(1.01)\end{array}$ & $\begin{array}{c}0.080 \\
(0.15)\end{array}$ \\
\hline Leverage & 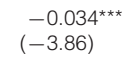 & $\begin{array}{l}-0.773^{\text {** }} \\
(-2.59)\end{array}$ & $\begin{array}{l}-0.552^{\star} \\
(-1.94)\end{array}$ \\
\hline$R \& D$ & - & $\begin{array}{l}13.233^{\star \star \star} \\
(12.71)\end{array}$ & $\begin{array}{l}8.431^{\star \star *} \\
(9.34)\end{array}$ \\
\hline CEO age & $\begin{array}{l}0.771^{*} \\
(1.88)\end{array}$ & $\begin{array}{l}3.596 \\
(0.28)\end{array}$ & $\begin{array}{l}-2.515 \\
(-0.23)\end{array}$ \\
\hline CEO age squared & $\begin{array}{l}-0.098^{*} \\
(-1.90)\end{array}$ & $\begin{array}{l}-0.415 \\
(-0.25)\end{array}$ & $\begin{array}{c}0.318 \\
(0.23)\end{array}$ \\
\hline CEO tenure & $\begin{array}{l}0.006 \\
(0.68)\end{array}$ & $\begin{array}{l}0.026 \\
(0.07)\end{array}$ & $\begin{array}{r}-0.031 \\
(-0.09)\end{array}$ \\
\hline CEO tenure squared & $\begin{array}{l}-0.002 \\
(-0.98)\end{array}$ & $\begin{array}{l}-0.018 \\
(-0.20)\end{array}$ & $\begin{array}{c}0.015 \\
(0.19)\end{array}$ \\
\hline CEO delta & $\begin{array}{l}-0.012^{\text {*** }} \\
(-3.37)\end{array}$ & $\begin{array}{l}-0.108 \\
(-0.78)\end{array}$ & $\begin{array}{c}-0.095 \\
(-0.84)\end{array}$ \\
\hline CEO vega & $\begin{array}{l}0.040^{* * *} \\
(5.42)\end{array}$ & $\begin{array}{l}0.602^{* *} \\
(2.17)\end{array}$ & $\begin{array}{l}0.423^{*} \\
(1.84)\end{array}$ \\
\hline Golden parachute & $\begin{array}{l}0.006^{\star *} \\
(2.36)\end{array}$ & $\begin{array}{c}0.100 \\
(1.13)\end{array}$ & $\begin{array}{c}0.120 \\
(1.58)\end{array}$ \\
\hline CEO-chair & $\begin{array}{l}-0.004^{*} \\
(-1.73)\end{array}$ & $\begin{array}{c}0.029 \\
(0.33)\end{array}$ & $\begin{array}{l}-0.006 \\
(-0.08)\end{array}$ \\
\hline Founder CEO & $\begin{array}{l}0.017^{\star * *} \\
(2.92)\end{array}$ & $\begin{array}{c}0.133 \\
(0.76)\end{array}$ & $\begin{array}{c}-0.024 \\
(-0.16)\end{array}$ \\
\hline Pseudo $R^{2}$ & N.A. & 0.294 & 0.277 \\
\hline No. of obs. & 9,352 & 8,479 & 8,415 \\
\hline
\end{tabular}




\section{B. Endogeneity Issues and Other Robustness Checks}

The results presented above suggest that CEO connections positively affect the extent and quality of corporate innovation investments. In this section, we conduct several tests to examine the substantiveness and robustness of this finding.

\section{Reverse Causality}

A primary concern is whether the result is attributable to reverse causality. For example, a CEO may attract a bigger network (e.g., from additional board memberships) because of innovation successes at his primary employer. In this case, our regressions would depict a positive relation between corporate innovation and CEO networks, even though this would simply be because CEOs of innovative firms attract more connections.

Faleye (2007) and Cheng (2008), among others, address this type of reverse causality problem by regressing the dependent variable on lagged values of the explanatory variable based on the argument that such historical values are largely predetermined. We implement this approach by regressing our measures of innovation 3 years in the future on CEO connections in the current year while ensuring that the same CEO remains in place during both years. ${ }^{6}$ As Panel A1 of Table 3 shows, we find a positive relation between future innovation activities and current CEO connections, which suggests that our results are not due to reverse causality problems.

We investigate this further by estimating regressions where we replace the annual CEO connections variable with the CEO's connections from his oldest position. This is based on the intuition that this measure is less likely to include innovation-induced connections because it reflects connections established long before the CEO has had a meaningful level of highly visible innovation successes and should be insignificant if our results are explained by reverse causality. ${ }^{7}$ As Panel A2 of Table 3 shows, this is not the case. Rather, we find a positive and significant association between corporate innovation and connections obtained from the CEO's oldest position.

As an alternative approach for addressing this issue, we estimate our models with lagged values of the dependent variables as additional control variables. This approach addresses the problems of unobserved heterogeneity and reverse causality by conditioning on the history of all independent variables and allowing past realizations of the dependent variable to affect its current level. The downside, of course, is that a lagged dependent variable absorbs much of the variation in the data, leaving other variables with little to explain even though they may in fact be theoretically relevant explanatory variables. As Panel A3 of Table 3 shows, we continue to find a positive and significant relation between $\mathrm{CEO}$ connections and each of R\&D investments and citations per patent after including the lagged value

\footnotetext{
${ }^{6}$ This is equivalent to regressing current innovation on the third lag of all explanatory variables. As an additional robustness check, we regress current innovation on the third lag of CEO connections and concurrent values of the other explanatory variables. Our results remain unchanged. We thank an anonymous referee for suggesting these tests.

${ }^{7}$ We recognize that this approach will not remedy reverse causality concerns if the old and contemporaneous variables are highly correlated. In our case, the correlation is only 0.42 .
} 
of each variable in our models, but the connections variable is not significant in the analogous patent regression, though it remains positive. Overall, these results suggest that our findings are not likely attributable to reverse causality.

\section{Firm Fixed Effects}

We also estimate firm fixed-effect regressions to control for unobservable time-invariant characteristics that may affect corporate innovation. Because our basic regressions are Tobit models (and therefore not amenable to firm fixed-effect estimation) and Poisson and negative binomial models result in significant data losses, we estimate these regressions using simple ordinary least squares (OLS) with standard errors clustered at the firm level. In results not tabulated for brevity,

\section{TABLE 3}

\section{CEO Connections and Corporate Innovation: Robustness Tests}

The dependent variables are the ratio of research and development (R\&D) expenditures to total assets, the natural logs of 1 plus patents applications eventually granted, and the natural log of 1 plus citations per patent. CEO connections is the natural log of 1 plus the detrended number of individuals with whom the chief executive officer (CEO) shares a common educational, employment, or social history in BoardEx. Connections from oldest job is the natural log of 1 plus CEO connections from his first position reported in BoardEx. In Panel A, the lagged dependent variable is the first lag of the dependent variable in each regression. In Panel B1, high ability equals 1 if the CEO attended an undergraduate program at a university or college with consistently high (top 20) SAT/ACT scores or secured his first executive-level positions before age 35 or won a professional recognition award at any point in his career or outperformed the industry median ROA during each of the 3 preceding years, and 0 otherwise. In Panel B2, high ability equals 1 if the firm received more patents than the median firm during each of the 3 preceding years of the CEO's tenure, and 0 otherwise. In Panel C, connections per employer is the natural log of 1 plus average CEO connections per employer while maximum connections is the natural $\log$ of 1 plus the number of connections from the position that provides the CEO with the most contacts. In Panel D, nondetrended CEO connections is the natural log of the number of individuals with whom the CEO shares a common educational, employment, or social history in BoardEx, combined CEO network is the natural log of 1 plus the detrended number of individuals with whom the CEO is connected through his direct contacts, and firms in CEO network is the natural log of 1 plus the detrended number of unique firms with which the CEO is connected through his direct contacts. Each regression includes the control variables in Table 2 as well as year and Fama-French (1997) 48 industry dummies. These variables are not reported to conserve space. Test statistics based on robust standard errors clustered at the CEO level are shown in parentheses. ${ }^{* \star *},{ }^{* *}$, and ${ }^{*}$ indicate significance at the $1 \%, 5 \%$, and $10 \%$ levels, respectively.

Panel A. Addressing Reverse Causality

\begin{tabular}{|c|c|c|c|c|c|c|c|c|c|}
\hline \multirow[b]{2}{*}{ Variables } & \multicolumn{3}{|c|}{$\begin{array}{c}\text { A1. 3-Year Forward } \\
\text { Dependent Variables }\end{array}$} & \multicolumn{3}{|c|}{ A2. Oldest Position } & \multicolumn{3}{|c|}{$\begin{array}{c}\text { A3. Lagged } \\
\text { Dependent Variables }\end{array}$} \\
\hline & $\mathrm{R} \& \mathrm{D}$ & Patents & Patent Cites & $R \& D$ & Patents & Patent Cites & $R \& D$ & Patents & Patent Cites \\
\hline CEO connections & $\begin{array}{l}0.008^{* * *} \\
(2.90)\end{array}$ & $\begin{array}{l}0.203^{*} \\
(1.84)\end{array}$ & $\begin{array}{l}0.223^{\star \star} \\
(2.51)\end{array}$ & - & - & - & $\begin{array}{l}0.0014^{\star \star \star} \\
(2.94)\end{array}$ & $\begin{array}{l}0.0084 \\
(0.48)\end{array}$ & $\begin{array}{l}0.0961^{\star \star *} \\
(2.80)\end{array}$ \\
\hline $\begin{array}{l}\text { Connections from } \\
\text { oldest job }\end{array}$ & - & - & - & $\begin{array}{l}0.003^{\star \star \star} \\
(2.91)\end{array}$ & $\begin{array}{l}0.086^{\star \star} \\
(2.19)\end{array}$ & $\begin{array}{l}0.068^{* *} \\
(2.06)\end{array}$ & - & - & - \\
\hline $\begin{array}{l}\text { Lagged dependent } \\
\text { variable }\end{array}$ & - & - & - & - & - & - & $\begin{array}{l}0.904^{* * \star} \\
(53.73)\end{array}$ & $\begin{array}{l}1.003^{\star \star \star} \\
(80.33)\end{array}$ & $\begin{array}{l}0.780^{\star \star \star} \\
(23.23)\end{array}$ \\
\hline Pseudo $R^{2}$ & N.A. & 0.308 & 0.310 & N.A. & 0.293 & 0.277 & N.A. & 0.547 & 0.345 \\
\hline No. of obs. & 3,571 & 3,052 & 3,019 & 9,352 & 8,479 & 8,415 & 7,615 & 6,820 & 6,761 \\
\hline
\end{tabular}

Panel B. CEO Connections, CEO Ability, and Corporate Innovation

\begin{tabular}{|c|c|c|c|c|c|c|}
\hline \multirow[b]{2}{*}{ Variables } & \multicolumn{3}{|c|}{ B1. Using Latent Ability Index } & \multicolumn{3}{|c|}{ B2. Using Innovation Ability } \\
\hline & R\&D & Patents & Patent Cites & $R \& D$ & Patents & Patent Cites \\
\hline CEO connections & $\begin{array}{l}0.009^{\star \star \star} \\
(4.61)\end{array}$ & $\begin{array}{l}0.280^{\star \star \star} \\
(3.95)\end{array}$ & $\begin{array}{l}0.183^{\text {} \star \star \star} \\
(2.83)\end{array}$ & $\begin{array}{l}0.008^{* * *} \\
(4.26)\end{array}$ & $\begin{array}{l}0.076 \\
(1.21)\end{array}$ & $\begin{array}{l}0.175^{\star \star} \\
(2.13)\end{array}$ \\
\hline High ability & $\begin{array}{l}0.029^{\star \star} \\
(2.37)\end{array}$ & $\begin{array}{l}0.819^{*} \\
(1.79)\end{array}$ & $\begin{array}{c}0.554 \\
(1.32)\end{array}$ & $\begin{array}{l}0.065^{\star \star \star} \\
(4.86)\end{array}$ & $\begin{array}{l}2.446^{\star * \star} \\
(5.69)\end{array}$ & $\begin{array}{l}2.850^{\star \star \star} \\
(5.91)\end{array}$ \\
\hline $\begin{array}{c}\text { CEO connections } \\
\times \text { High ability }\end{array}$ & $\begin{array}{l}-0.005^{\star \star} \\
(-2.10)\end{array}$ & $\begin{array}{l}-0.160^{*} \\
(-1.81)\end{array}$ & $\begin{array}{l}-0.109 \\
(-1.38)\end{array}$ & $\begin{array}{l}-0.006^{\star \star} \\
(-2.31)\end{array}$ & $\begin{array}{l}-0.006 \\
(-0.07)\end{array}$ & $\begin{array}{l}-0.232^{\star \star} \\
(-2.50)\end{array}$ \\
\hline Pseudo $R^{2}$ & N.A. & 0.294 & 0.277 & N.A. & 0.394 & 0.325 \\
\hline No. of obs. & 9,352 & 8,479 & 8,415 & 6,045 & 5,456 & 5,418 \\
\hline
\end{tabular}


TABLE 3 (continued)

CEO Connections and Corporate Innovation: Robustness Tests

Panel C. CEO Connections, Propensity to Change Jobs, and Corporate Innovation

\begin{tabular}{|c|c|c|c|c|c|c|}
\hline \multirow[b]{2}{*}{ Variables } & \multicolumn{3}{|c|}{ C1. Average Connections } & \multicolumn{3}{|c|}{ C2. Maximum Connections } \\
\hline & $R \& D$ & Patents & Patent Cites & $R \& D$ & Patents & Patent Cites \\
\hline Connections per employer & $\begin{array}{l}0.008^{\star \star \star} \\
(5.73)\end{array}$ & $\begin{array}{l}0.191^{\star \star *} \\
(3.86)\end{array}$ & $\begin{array}{l}0.135^{\text {*** }} \\
(3.11)\end{array}$ & - & - & - \\
\hline Maximum connections & - & - & - & $\begin{array}{l}0.277^{\text {***}} \\
(5.20)\end{array}$ & $\begin{array}{l}0.183^{\text {***}} \\
(3.84)\end{array}$ & $\begin{array}{l}0.010^{\star * \star} \\
(6.27)\end{array}$ \\
\hline Pseudo $R^{2}$ & N.A. & 0.297 & 0.281 & 0.296 & 0.278 & N.A. \\
\hline No. of obs. & 8,664 & 7,831 & 7,770 & 8,479 & 8,415 & 9,352 \\
\hline
\end{tabular}

Panel D. Other Measures of CEO Connections

\begin{tabular}{|c|c|c|c|c|c|c|c|c|c|}
\hline \multirow[b]{2}{*}{ Variables } & \multicolumn{3}{|c|}{ D1. Raw Connections } & \multicolumn{3}{|c|}{ D2. Direct and Indirect } & \multicolumn{3}{|c|}{ D3. Firms in CEO Network } \\
\hline & $R \& D$ & Patents & Patent Cites & R\&D & Patents & Patent Cites & $R \& D$ & Patents & $\underline{\text { Patent Cites }}$ \\
\hline $\begin{array}{l}\text { Nondetrended CEO } \\
\text { connections }\end{array}$ & $\begin{array}{l}0.003^{\star * *} \\
(3.21)\end{array}$ & $\begin{array}{l}0.088^{\star \star \star} \\
(2.72)\end{array}$ & $\begin{array}{l}0.043^{*} \\
(1.65)\end{array}$ & - & - & - & - & - & - \\
\hline $\begin{array}{l}\text { Combined CEO } \\
\text { network }\end{array}$ & - & - & - & $\begin{array}{l}0.014^{\star \star \star} \\
(6.72)\end{array}$ & $\begin{array}{l}0.318^{\star \star \star} \\
(3.83)\end{array}$ & $\begin{array}{l}0.243^{\star \star \star} \\
(3.12)\end{array}$ & - & - & - \\
\hline $\begin{array}{l}\text { Firms in CEO } \\
\text { network }\end{array}$ & - & - & - & - & - & - & $\begin{array}{l}0.011^{\star \star \star} \\
(6.79)\end{array}$ & $\begin{array}{l}0.188^{\star \star \star} \\
(2.97)\end{array}$ & $\begin{array}{l}0.134^{* *} \\
(2.34)\end{array}$ \\
\hline Pseudo/adjusted $R^{2}$ & N.A. & 0.293 & 0.277 & N.A. & 0.294 & 0.277 & N.A. & 0.293 & 0.277 \\
\hline No. of obs. & 9,352 & 8,479 & 8,415 & 9,352 & 8,479 & 8,415 & 9,352 & 8,479 & 8,415 \\
\hline
\end{tabular}

we find that CEO connections is positive and significant in the patent regression ( $p$-value $=0.04)$. It is also weakly significant in the patent citation regression $(p$-value $=0.14)$ but insignificant in the $\mathrm{R} \& \mathrm{D}$ regression. These relatively weak results are not surprising as fixed-effects models rely exclusively on within-subject variations to identify the effects of explanatory variables, and CEO connections do not vary much from year to year in our sample. ${ }^{8}$

\section{Correlated Omitted Variables}

A related concern is that our results are driven by correlated omitted variables, for example, CEO ability. High-ability CEOs are likely to be recruited more frequently and/or get nominated for service on more corporate boards, which would give them larger networks. Meanwhile, R\&D projects initiated by such CEOs will tend to be of higher quality, thereby increasing the likelihood of board approval (leading to higher R\&D expenditures) and resulting in more and better quality patents that are widely cited. Thus, we would find a positive association between CEO connections and our measures of corporate innovation but the relation would be driven by underlying CEO ability.

We develop four proxies for underlying ability to address this concern. The first proxy equals 1 if the $\mathrm{CEO}$ attended an undergraduate program at a university or college with consistently high (top 20) SAT/ACT scores, and 0 otherwise. This is based on the intuition that individuals matriculating into elite schools are more likely to possess higher ability compared to those matriculating into other

\footnotetext{
${ }^{8}$ The median 1-year change in total CEO connections is 1 (compared to the median connections of 103 ), and $41 \%$ of the sample experienced no change in CEO connections from one year to the next.
} 
schools. The second proxy equals 1 for CEOs that secured their first executivelevel positions before age 35, and 0 otherwise. This is based on the rationale that high-ability individuals are more likely to climb the corporate ladder faster than others. The third proxy equals 1 if the CEO wins a professional recognition award (e.g., CEO of the year) at any point in his career, and 0 otherwise. This captures explicit outside recognition of the CEO's ability and performance. Our final proxy equals 1 if the CEO outperforms the industry median return on assets (ROA) during each of the three preceding years, and 0 otherwise. This is based on the argument that high ability should manifest in measurable results that exceed peer performance.

Because these proxies likely capture different dimensions of CEO ability, we create a high-ability indicator variable that equals 1 if the CEO qualifies as high ability under any of the four proxies, and 0 otherwise. We then estimate regressions analogous to those in Table 2 but with controls for CEO ability. We also include an interaction term between CEO ability and connections to test whether the effect of connections on corporate innovation differs on the basis of CEO ability. Results are shown in Panel B1 of Table 3.

As the table shows, CEO ability is positively associated with corporate innovation. Yet including $\mathrm{CEO}$ ability in the regressions does not diminish the effects of CEO connections. Thus, it does not appear that our results are driven by underlying CEO ability. Table 3 also shows that the interaction term between CEO connections and the high-ability indicator variable is negative, suggesting that corporate innovation is less sensitive to CEO connections among high-ability CEOs. As we show later, CEO connections facilitate corporate innovation by providing information advantages and an implicit labor market insurance. High-ability CEOs, by definition, have less need of information from others and less need of the labor market benefits of a large personal network because their high ability makes them inherently more desirable to employers. As a result, high-ability CEOs are less likely to derive innovation-relevant benefits from personal connections, which is reflected in the lower sensitivity of corporate innovation to connections among these CEOs.

The above notwithstanding, skeptical readers might argue that the dimension of CEO ability that attracts a larger personal network is not necessarily captured by our measures of underlying ability. For example, it is possible that the CEO's propensity to be recruited by other firms or to otherwise attract a larger network is correlated more with his ability to innovate than with his latent ability. Therefore, we create an additional high-ability indicator variable that equals 1 if the firm received more patents than the median firm during each of the 3 preceding years of the CEO's tenure. We then repeat our regressions using this variable, excluding firms whose CEOs have tenures of less than 3 years because the ability variable is not defined for those firms. Results are presented in Panel B2 of Table 3, showing that our findings remain unchanged.

We also recognize that a CEO may change employment frequently for reasons other than ability-induced recruitment by other firms. For example, optimistic, adventurous, and/or risk-loving CEOs tend to change jobs more often and may also be more likely to engage in corporate innovation, which would create a spurious relation between CEO connections and corporate innovation. 
We address this concern by creating two additional network variables that remove the effects of job-hopping from the CEO's personal connections. These variables are the number of connections per position and connections from the position that provides the largest number of contacts, respectively. We report results of regressions using these measures in Panel $\mathrm{C}$ of Table 3. Each variable is significantly and positively associated with our measures of corporate innovation.

\section{Potential Industry Effects}

Highly connected CEOs may cluster in innovative industries so that regressions pooling all firms may incorrectly show a positive relation between CEO connections and corporate innovation. We include industry dummies in our regressions to minimize this concern. Nevertheless, we estimate OLS regressions where the sample is restricted to firm-years with nonzero values on our measures of innovation. We continue to find a positive and significant relation between CEO connections and each of R\&D and successful patent applications. However, the relation is no longer significant in the patent citation regression. We do not tabulate these results for brevity.

A related concern is that our results are potentially contaminated by the fact that certain $R \& D$ expenses are capitalized in some industries (mainly the software industry) and thus are not reported as R\&D expenditures on the income statement. We examine the robustness of our results to this phenomenon by excluding software companies (Standard Industrial Classification (SIC) code 7372) from the sample and re-estimating our models. Results remain unchanged and are not tabulated to conserve space.

\section{Instrumental Variable Regressions}

In addition to the foregoing, we estimate instrumental variable two-stage least squares (2SLS) regressions to address potential endogeneity arising from unobservable heterogeneity. The basic requirement for validity is that instruments have no effect on the dependent variable other than through their effect on the suspected endogenous independent variable. We employ three instruments that statistically meet this requirement. The first instrument is the number of FamaFrench (1997) industries in which the CEO has worked in the past. We choose this variable because the number of past industries in which the CEO has worked is highly correlated with the number of individuals in the CEO's network, and it is less likely that this variable has a direct effect on corporate innovation. For example, it is not clear a priori that a CEO who spent his entire career in the pharmaceutical industry will innovate more or less than a CEO who is experienced in other industries besides pharmaceuticals. The second instrument is a binary variable indicating whether the CEO earned a graduate degree in any field from any institution, and the third instrument is a binary variable indicating whether the CEO earned the MBA degree specifically. ${ }^{9}$ Each of these variables is highly significant

\footnotetext{
${ }^{9}$ Sixty-five percent of CEOs with graduate degrees also earned a master of business administration (MBA) degree so that neither variable is subsumed in the other.
} 
in a first-stage regression predicting CEO connections $(F$-statistic $=51.4)$, and statistical tests indicate that none is directly associated with our measures of corporate innovation. Second-stage regressions show a positive and significant relation between corporate innovation and (predicted) CEO connections, but we do not tabulate results to conserve space.

\section{Other Measures of CEO Connections}

As a further test of the robustness of our results, we employ other measures of CEO connections to examine whether our results are dependent on the specific measures used in our main tests. As discussed in Section II.A.2, we detrended our network measures to remove the time trend that arises from the fact that individuals are connected in all future periods once a connection is established between them. We examine the sensitivity of our results to this possibility by estimating regressions where we use actual connections rather than the detrended values. Our results remain unchanged. Furthermore, we recognize that a simple count of the CEO's direct contacts may not completely capture differences in the size of CEO networks as some direct contacts have larger networks than others. We examine the robustness of our results to such indirect network effects by estimating two additional sets of regressions. The first uses the number of individuals in the combined networks of the CEO's contacts, and the second uses the number of companies to which the CEO is connected through the individuals in his network. In each case, we find a positive relation between $\mathrm{CEO}$ connections and corporate innovation, as shown in Panel D of Table 3.

\section{Conclusion on Robustness Tests}

Overall, the tests discussed in this section indicate that our basic findings are less likely to be mere artifacts of confounding underlying issues, reverse causality, or other endogeneity problems. Rather, they suggest that corporate innovation increases with the size of the CEO's personal network. Yet this also raises the question of whether such increases in innovation are value enhancing or represent wasteful overinvestment. We believe that the evidence is more consistent with the former view for the following reasons. First, overinvestment is more likely a concern for R\&D spending and less so for patents and patent citations. Because our patent and citation regressions control for the level of R\&D expenditures, the results imply that better-connected CEOs receive more and better-cited patents relative to CEOs with fewer connections at similar levels of R\&D spending, which is inconsistent with overinvestment in R\&D. Second, we estimate additional regressions where the dependent variables are patents and citations per average dollar of R\&D spending in the preceding 3 years. We find a positive effect for CEO connections in these regressions, results of which are available from the authors but not tabulated here to conserve space. Finally, we estimate regressions of firm performance on innovation predicted by CEO connections to explore the existence of a direct link between connections-induced innovation and firm performance. As Table 4 shows, the level of innovation predicted by CEO connections is significantly and positively associated with firm performance as measured by ROA 


\section{TABLE 4}

\section{CEO Connections, Corporate Innovation, and Firm Performance}

The dependent variables are the ratio of income before extraordinary items to total assets (ROA) and the ratio of the sum of the market value of common equity and the book values of preferred equity and long-term debt to the book value of assets (Tobin's q). Predicted research and development (R\&D), predicted patents, and predicted patent cites are the predicted values from the regression of each variable on chief executive officer (CEO) connections, which is the natural log of 1 plus the detrended number of individuals with whom the CEO shares a common educational, employment, or social history in BoardEx. Firm size is the natural log of total assets. Leverage is the ratio of long-term debt (including current portion) to total assets. Capital expenditures is the ratio of capital expenditures to total assets. Board size is the natural log of the number of directors. Classified board equals 1 if directors are elected to staggered terms, and 0 otherwise. CEO tenure is the natural log of the number of years for which the CEO has been in office. CEO delta is the natural log of $10^{-6}$ times the dollar sensitivity of CEO firm-specific wealth (option and stockholdings) to $1 \%$ change in the firm's stock price. CEO-chair equals 1 if the CEO also serves as board chair, and 0 otherwise. Founder CEO equals 1 if BoardEx identifies the CEO as a founder or cofounder of the company, and 0 otherwise. Each regression includes year and Fama-French (1997) 48 industry dummies. Test statistics based on robust standard errors clustered at the CEO level are shown in parentheses. ${ }^{\star \star *},{ }^{* *}$, and ${ }^{*}$ indicate significance at the $1 \%, 5 \%$, and $10 \%$ levels, respectively.

\begin{tabular}{|c|c|c|c|c|c|c|}
\hline \multirow[b]{2}{*}{ Variables } & \multicolumn{3}{|c|}{$\mathrm{ROA}$} & \multicolumn{3}{|c|}{ Tobin's q } \\
\hline & 1 & 2 & 3 & 1 & 2 & 3 \\
\hline Predicted R\&D & $\begin{array}{l}0.665^{* *} \\
(2.080)\end{array}$ & - & - & $\begin{array}{l}16.771^{\star \star \star} \\
(4.014)\end{array}$ & - & - \\
\hline Predicted patents & - & $\begin{array}{l}0.005^{\star \star} \\
(2.091)\end{array}$ & - & - & $\begin{array}{l}0.119^{\star \star \star} \\
(4.008)\end{array}$ & - \\
\hline Predicted patent cites & - & - & $\begin{array}{l}0.009^{\star \star} \\
(2.140)\end{array}$ & - & - & $\begin{array}{l}0.221^{\star \star \star} \\
(4.136)\end{array}$ \\
\hline Firm size & $\begin{array}{l}-0.000 \\
(-0.097)\end{array}$ & $\begin{array}{l}-0.001 \\
(-0.361)\end{array}$ & $\begin{array}{l}-0.001 \\
(-0.447)\end{array}$ & $\begin{array}{l}-0.097^{\star \star \star} \\
(-4.709)\end{array}$ & $\begin{array}{l}-0.092^{\star \star \star} \\
(-4.163)\end{array}$ & $\begin{array}{l}-0.092^{\star \star \star} \\
(-4.153)\end{array}$ \\
\hline Leverage & $\begin{array}{l}-0.089^{\star \star \star} \\
(-7.005)\end{array}$ & $\begin{array}{l}-0.089^{\star * \star} \\
(-6.620)\end{array}$ & $\begin{array}{l}-0.088^{\star \star \star} \\
(-6.518)\end{array}$ & $\begin{array}{l}-0.631^{\star \star \star} \\
(-3.611)\end{array}$ & $\begin{array}{l}-0.622^{\star \star \star} \\
(-3.406)\end{array}$ & $\begin{array}{l}-0.620^{\star * *} \\
(-3.376)\end{array}$ \\
\hline Capital expenditures & $\begin{array}{c}0.536^{\star \star *} \\
(15.633)\end{array}$ & $\begin{array}{c}0.542^{\star \star \star} \\
(15.258)\end{array}$ & $\begin{array}{c}0.542^{\star \star \star} \\
(15.219)\end{array}$ & $\begin{array}{c}-0.360 \\
(-0.776)\end{array}$ & $\begin{array}{l}-0.292 \\
(-0.590)\end{array}$ & $\begin{array}{c}-0.292 \\
(-0.587)\end{array}$ \\
\hline Board size & $\begin{array}{c}0.012^{*} \\
(1.828)\end{array}$ & $\begin{array}{l}0.015^{\star \star} \\
(2.196)\end{array}$ & $\begin{array}{l}0.016^{\star *} \\
(2.285)\end{array}$ & $\begin{array}{l}-0.304^{\star \star *} \\
(-3.523)\end{array}$ & $\begin{array}{l}-0.338^{\star \star \star} \\
(-3.671)\end{array}$ & $\begin{array}{l}-0.339^{\star \star *} \\
(-3.614)\end{array}$ \\
\hline Classified board & $\begin{array}{c}-0.002 \\
(-0.720)\end{array}$ & $\begin{array}{l}-0.002 \\
(-0.568)\end{array}$ & $\begin{array}{l}-0.002 \\
(-0.561)\end{array}$ & $\begin{array}{l}-0.095^{\star \star} \\
(-2.385)\end{array}$ & $\begin{array}{l}-0.103^{\star \star} \\
(-2.452)\end{array}$ & $\begin{array}{l}-0.104^{\star \star} \\
(-2.477)\end{array}$ \\
\hline CEO tenure & $\begin{array}{c}0.006^{* *} \\
(2.134)\end{array}$ & $\begin{array}{c}0.006^{*} \\
(1.941)\end{array}$ & $\begin{array}{c}0.006^{*} \\
(1.880)\end{array}$ & $\begin{array}{l}-0.073^{\star *} \\
(-1.969)\end{array}$ & $\begin{array}{l}-0.063 \\
(-1.599)\end{array}$ & $\begin{array}{c}-0.060 \\
(-1.528)\end{array}$ \\
\hline CEO delta & $\begin{array}{l}0.025^{\text {*** }} \\
(6.295)\end{array}$ & $\begin{array}{l}0.025^{\text {***}} \\
(6.068)\end{array}$ & $\begin{array}{l}0.025^{\star \star \star} \\
(6.048)\end{array}$ & $\begin{array}{l}0.639^{* * \star} \\
(9.667)\end{array}$ & $\begin{array}{l}0.662^{\star \star \star} \\
(9.460)\end{array}$ & $\begin{array}{l}0.662^{\star \star \star} \\
(9.392)\end{array}$ \\
\hline CEO-chair & $\begin{array}{l}-0.002 \\
(-0.787)\end{array}$ & $\begin{array}{c}-0.002 \\
(-0.824)\end{array}$ & $\begin{array}{l}-0.002 \\
(-0.802)\end{array}$ & $\begin{array}{l}-0.164^{\star \star \star} \\
(-4.317)\end{array}$ & $\begin{array}{l}-0.178^{\text {*ᄎ }} \\
(-4.427)\end{array}$ & $\begin{array}{l}-0.177^{* * *} \\
(-4.383)\end{array}$ \\
\hline Founder CEO & $\begin{array}{l}-0.023^{\star \star \star} \\
(-3.242)\end{array}$ & $\begin{array}{l}-0.023^{\star \star \star} \\
(-3.143)\end{array}$ & $\begin{array}{l}-0.022^{\star \star \star} \\
(-3.097)\end{array}$ & $\begin{array}{c}0.146 \\
(1.454)\end{array}$ & $\begin{array}{c}0.136 \\
(1.339)\end{array}$ & $\begin{array}{c}0.137 \\
(1.345)\end{array}$ \\
\hline $\mathrm{ROA}$ & - & - & - & $\begin{array}{c}6.465^{\star \star \star} \\
(16.632)\end{array}$ & $\begin{array}{c}6.413^{\star * *} \\
(16.052)\end{array}$ & 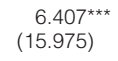 \\
\hline No. of obs. & 9,352 & 8,479 & 8,415 & 8,478 & 7,625 & 7,561 \\
\hline Adjusted $R^{2}$ & 0.237 & 0.238 & 0.238 & 0.491 & 0.492 & 0.492 \\
\hline
\end{tabular}

and Tobin's $q .{ }^{10}$ In all instances, these tests are inconsistent with the argument that better-connected CEOs engage in inefficient overinvestment in corporate innovation. Next, we turn to the potential channels through which CEO connections encourage corporate innovation investments.

\section{Potential Channels for Facilitating Corporate Innovation}

We consider two channels: information effects and labor market effects. We discuss and evaluate each in turn, recognizing that the two are not necessarily mutually exclusive.

\footnotetext{
${ }^{10}$ We define Tobin's $q$ as the market value of common equity plus the book values of preferred equity and long-term debt divided by the book value of assets.
} 


\section{A. Information Channel}

A basic characteristic of networks is that they enable the propagation of information along their different nodes. In particular, prior research shows that the network of top executives facilitates the dissemination of business information that enhances the quality of strategic decisions (McDonald et al. (2008), Schonlau and Singh (2009)). Thus, better-connected CEOs may innovate more because they have access to information that allows them to identify innovation opportunities more efficiently and reduces the uncertainty surrounding such innovation projects. We label this the "information channel hypothesis."

Testing this hypothesis requires us to identify the extent to which information that is valuable for innovation is present in each CEO's personal network and then test whether firms whose CEOs have greater access to such information innovate more than otherwise similar firms whose CEOs have similarly sized networks. We presume that executives at innovative firms are more likely to possess innovationrelevant information so that a CEO's access to such information increases with the extent to which his connections are affiliated with such firms. Thus, we begin by calculating the fraction of each CEO's total contacts that are affiliated with innovative firms, defined as those with positive R\&D investment. ${ }^{11}$ Next, we estimate our innovation regressions with this variable as an additional explanatory variable, expecting it to be positive and significant after controlling for network size if network information flow provides a channel for CEO connections to facilitate corporate innovation.

The first three columns of Table 5 present results of these regressions. In the first column where the dependent variable is R\&D investment rate, the information variable is positive and significant at the $1 \%$ level. Thus, after controlling for network size, access to relevant information in the network significantly influences the extent of corporate R\&D investments. For the CEO with a median-sized network, an increase from the first quartile to the third quartile in the fraction of direct contacts who are affiliated with innovative firms is associated with an increase of 80 basis points in R\&D investment, holding all other variables at their sample means. This amounts to an increase of $27.6 \%$ in $R \& D$ investment rate relative to its sample mean. We obtain similar results for patents and citations per patent in the second and third columns, with an interquartile change in the fraction of connections derived from individuals affiliated with innovative firms being associated with increases of $17.6 \%$ and $7.9 \%$ in patents and citations per patent for the CEO with a median-sized network. We obtain similar results in untabulated regressions where we measure innovative connections relative to the total of the CEO's direct and indirect connections as well as the number of firms in the CEO's network.

As a further test of the information channel hypothesis, we examine whether the extent to which a CEO's personal network flows with innovation-relevant information (as opposed to other types of information) has a greater effect on corporate innovation as one would expect under the hypothesis. However, we cannot include the respective fractions of each CEO's connections that are affiliated with

\footnotetext{
${ }^{11}$ Results are similar when we define innovative firms based on patents and patent citations and when we use third-quartile values as the threshold for innovativeness.
} 
innovative and less innovative firms in the same regressions because each is a linear combination of the other. Therefore, we regress total CEO connections on the percentage of innovative firms in the CEO's network and classify the predicted value of CEO connections as the portion of the CEO's network that is most likely to contain innovation-relevant information. We classify the orthogonal residual as less likely to contain such information and expect the predicted value to have a greater effect on corporate innovation under the information channel hypothesis.

The fourth through sixth columns of Table 5 present results of our innovation regressions using these variables in place of the original CEO connections variable. In the fourth column, both types of connections are significantly and positively associated with $R \& D$ investment rate. However, the economic impact is much larger for the innovation-information component. An interquartile change in this portion of CEO connections is associated with an increase of $29.3 \%$ in R\&D investment rate, compared to an increase of only $7.3 \%$ for a similar change in the residual component. We obtain similar patterns of increases for patents $(22.1 \%$ vs. $9.2 \%)$ and citations per patent $(9.5 \%$ vs. $3.0 \%)$ in the fifth and sixth columns, respectively. In all, these tests suggest that access to network information is an important channel through which CEO connections enhance corporate innovation investments.

\section{TABLE 5}

CEO Connections and Corporate Innovation: The Role of Network Information

CEO connections is the natural log of 1 plus the detrended number of individuals with whom the chief executive officer (CEO) shares a common educational, employment, or social history in BoardEx. Innovating connections is the fraction of each CEO's total contacts that are affiliated with innovative firms, that is, those with positive research and development (R\&D) investment. R\&D connections is the fitted value from regressing CEO connections on the percentage of firms in the CEO's network that have positive R\&D expenditures. Non-R\&D connections is the residual from the same regression. Each regression includes the control variables in Table 2 as well as year and Fama-French (1997) 48 industry dummies. These variables are not reported to conserve space. Test statistics based on robust standard errors clustered at the CEO level are shown in parentheses. ${ }^{* *}$ and ${ }^{* *}$ indicate significance at the $1 \%$ and $5 \%$ levels, respectively.

\begin{tabular}{|c|c|c|c|c|c|c|}
\hline \multirow[b]{2}{*}{ Variables } & \multicolumn{3}{|c|}{$\begin{array}{l}\text { Panel A. Connections to } \\
\text { Innovative Individuals }\end{array}$} & \multicolumn{3}{|c|}{$\begin{array}{c}\text { Panel B. Connections to } \\
\text { Innovative Firms }\end{array}$} \\
\hline & $R \& D$ & Patents & Patent Cites & $R \& D$ & Patents & Patent Cites \\
\hline CEO connections & $\begin{array}{l}0.005^{\star \star \star} \\
(3.52)\end{array}$ & $\begin{array}{l}0.167^{\star \star \star} \\
(2.81)\end{array}$ & $\begin{array}{l}0.103^{\star \star} \\
(1.98)\end{array}$ & - & - & - \\
\hline Innovating connections & $\begin{array}{l}0.078^{* * *} \\
(10.20)\end{array}$ & $\begin{array}{l}1.221^{\star \star \star} \\
(4.51)\end{array}$ & $\begin{array}{l}1.060^{\star \star \star} \\
(4.34)\end{array}$ & - & - & - \\
\hline R\&D connections & - & - & - & $\begin{array}{l}0.090^{\star \star \star} \\
(10.70)\end{array}$ & $\begin{array}{l}1.497^{\star \star \star} \\
(5.07)\end{array}$ & $\begin{array}{l}1.257^{\star \star \star} \\
(4.76)\end{array}$ \\
\hline Non-R\&D connections & - & - & - & $\begin{array}{l}0.005^{\star \star \star} \\
(3.52)\end{array}$ & $\begin{array}{l}0.167^{\star \star \star} \\
(2.81)\end{array}$ & $\begin{array}{l}0.103^{\star \star} \\
(1.98)\end{array}$ \\
\hline Pseudo $R^{2}$ & N.A. & 0.295 & 0.279 & N.A. & 0.295 & 0.279 \\
\hline No. of obs. & 9,314 & 8,443 & 8,379 & 9,314 & 8,443 & 8,379 \\
\hline
\end{tabular}

\section{B. Labor Market Channel}

Prior research in sociology and labor economics suggests that a principal benefit of personal networks is that they improve the efficiency and outcome of the job search process. In a seminal study, Granovetter (1974) shows that the most effective means of finding a job is through personal contacts. More recently, Mazerolle and Singh (2004) show that social networks improve the likelihood of re-employment following job displacement, and Cingano and Rosolia (2012) 
show that the duration of unemployment for a displaced worker declines significantly with the quality of that worker's personal network. These studies imply that a CEO's personal connections can help in searching for and securing a new position following the termination of current employment. Because the prospect of job loss following unsuccessful innovation attempts is a potential deterrent to investments in risky innovation, personal connections can facilitate such investments by providing the CEO with implicit labor market insurance.

We employ several tests to evaluate this hypothesis. First, we examine whether personal connections facilitate the CEO's labor-market re-entry following forced turnover. We obtain forced CEO turnover data for 1997-2002 from Faleye (2007) and extend the data to 2006 following the same methodology as in that study. This yields a total of 204 CEO dismissals over 1997-2006. Of these CEOs, 35 obtained another top-level position (CEO, chief operating officer, president, vice president, or other executive director) by the end of 2010 , for an unconditional re-employment rate of $17.2 \%$.

Next, we estimate logistic regressions where the dependent variable equals 1 if the departed CEO obtains a top-level position at another firm, and 0 otherwise. We control for other factors that potentially affect the CEO's ability and/or incentive to obtain another job, including age, tenure at terminated job, golden parachute coverage at previous position, firm size of the previous employer, and industry-adjusted operating performance of the previous employer. We also include year and industry fixed effects. We present results in Panel A of Table 6.

In the first column of Table 6, the CEO network variable is positive and significant at the $5 \%$ level. The model's coefficients imply that the probability of re-employment increases from $8.1 \%$ for the first-quartile CEO on personal connections to $36.4 \%$ for the third-quartile CEO when other variables are evaluated at their sample means. Because the sample unconditional probability of re-employment is only $17.2 \%$, this is an increase of $164.5 \%$ in the probability of labor market re-entry. ${ }^{12}$

We recognize that a simple count of the CEO's direct contacts may not completely capture the labor market effects of CEO connections because it values each contact equally. Therefore, we estimate additional regressions that allow for differences in the labor market utility of individuals in the CEO's network. The first regression uses the number of individuals in the combined networks of the CEO's contacts and the second uses the number of firms to which the CEO is personally connected through the individuals in his network. We present results of these tests in the second and third columns of Panel A in Table 6. In both cases, we obtain results that are similar to those in the first column.

As an additional test of the impact of CEO connections on post-termination employment outcomes, we examine the effect of personal connections on board appointments and departures in the 5 years following forced CEO turnover. First, we classify each dismissed CEO as large network or small network, based on whether his personal connections exceed the full-sample median, and then

\footnotetext{
${ }^{12}$ We obtain similar results in regressions using the sample of all 1,108 CEO turnovers where the departing CEO is not deceased. These results are not tabulated to conserve space but are available from the authors.
} 
The sample consists of 204 chief executive officers (CEOs) who were dismissed from their positions during 1997-2006. In Panel A, the dependent variable equals 1 if the CEO obtains another top-level position following forced turnover, and 0 otherwise. In Panel B, the dependent variable is net board seats gained, defined as the number of new board appointments within 5 years following dismissal minus the number of board memberships (excluding primary employer) as of the time of termination that were relinquished within 5 years of forced turnover. CEO connections is the natural log of 1 plus the detrended number of individuals with whom the CEO shares a common educational, employment, or social history in BoardEx. Combined CEO network is the natural log of 1 plus the detrended number of individuals with whom the CEO is connected through his direct contacts. Firms in CEO network is the natural log of 1 plus the detrended number of unique firms with which the CEO is connected through his direct contacts. Previous firm size is the natural log of the CEO's previous employer's total assets. Previous firm ROA is the previous employer's average return on assets (income before extraordinary items divided by total assets) less its Fama and French (1997) 48-industry median ROA in the previous 3 years. Golden parachute equals 1 if the previous employer has a golden parachute arrangement in place for the CEO, and 0 otherwise. Founder CEO equals 1 if BoardEx identifies the CEO as a founder or cofounder of the previous employer. CEO age is the natural log of CEO age in years at the time of termination. CEO tenure is the natural log of the number of years for which the CEO served in office at the previous employer. Each regression includes year and Fama-French (1997) 48 industry dummies. Robust standard errors are shown in parentheses. ${ }^{* \star},{ }^{* *}$, and * indicate significance at the $1 \%, 5 \%$, and $10 \%$ levels, respectively.

Panel A. Variables

CEO connections

Combined CEO network

Firms in CEO network

Previous firm size

Previous firm ROA

Golden parachute

Founder CEO

CEO age

CEO age squared

CEO tenure

CEO tenure squared

Pseudo/adjusted $R^{2}$

No. of obs.
New Management Position

\begin{tabular}{|c|c|c|}
\hline 1 & 2 & 3 \\
\hline $\begin{array}{c}1.103^{\star \star} \\
(0.480)\end{array}$ & - & - \\
\hline- & $\begin{array}{l}1.382^{\star *} \\
(0.665)\end{array}$ & - \\
\hline- & - & $\begin{array}{l}0.961^{\star \star} \\
(0.478)\end{array}$ \\
\hline $\begin{array}{r}-0.384 \\
(0.360)\end{array}$ & $\begin{array}{r}-0.378 \\
(0.359)\end{array}$ & $\begin{array}{r}-0.333 \\
(0.352)\end{array}$ \\
\hline $\begin{array}{c}1.318 \\
(3.205)\end{array}$ & $\begin{array}{c}1.394 \\
(3.182)\end{array}$ & $\begin{array}{c}1.249 \\
(3.198)\end{array}$ \\
\hline $\begin{array}{c}0.125 \\
(0.872)\end{array}$ & $\begin{array}{c}-0.031 \\
(0.853)\end{array}$ & $\begin{array}{c}0.051 \\
(0.855)\end{array}$ \\
\hline $\begin{array}{c}1.733 \\
(2.724)\end{array}$ & $\begin{array}{c}1.787 \\
(2.676)\end{array}$ & $\begin{array}{c}1.412 \\
(2.632)\end{array}$ \\
\hline $\begin{array}{c}45.579 \\
(242.363)\end{array}$ & $\begin{array}{c}24.646 \\
(234.294)\end{array}$ & $\begin{array}{c}32.201 \\
(233.172)\end{array}$ \\
\hline $\begin{array}{l}-6.109 \\
(31.138)\end{array}$ & $\begin{array}{l}-3.432 \\
(30.097)\end{array}$ & $\begin{array}{l}-4.433 \\
(29.957)\end{array}$ \\
\hline $\begin{array}{c}-16.862^{\star \star \star} \\
(4.610)\end{array}$ & $\begin{array}{c}-15.861^{\star \star \star} \\
(4.381)\end{array}$ & $\begin{array}{c}-16.008^{\star \star \star} \\
(4.370)\end{array}$ \\
\hline $\begin{array}{l}3.485^{\star \star \star} \\
(1.182)\end{array}$ & $\begin{array}{l}3.215^{\star \star \star} \\
(1.125)\end{array}$ & $\begin{array}{l}3.268^{* \star *} \\
(1.124)\end{array}$ \\
\hline 0.429 & 0.426 & 0.425 \\
\hline 204 & 204 & 204 \\
\hline
\end{tabular}

Panel B.

Net Board Seats Gained

$\frac{1}{\begin{array}{c}0.428^{* *} \\ (0.188)\end{array}} \frac{2}{-} \frac{3}{-}$

compare post-termination board appointments and departures for the two groups. Dismissed large-network CEOs were subsequently appointed to an average of 2.14 new boards and departed 0.47 boards, for an average net gain in board memberships of 1.67. In contrast, dismissed small-network CEOs received 0.65 new board appointments and departed 0.15 boards, for an average net gain in board memberships of only 0.50 boards. The differences are each significant at the $1 \%$ level. Next, we estimate regressions of net board seats gained on our measures of CEO connections and the control variables used in the post-termination employment regressions described earlier. As Panel B of Table 6 shows, net board seats gained increase significantly with CEO connections.

These results suggest that a large personal network mitigates the adverse career effects of CEO job losses and are consistent with the hypothesis that personal connections provide implicit labor market insurance for the CEO. Next, we 
examine whether this insurance is associated with increased investments in corporate innovation as predicted by the employment hedge hypothesis. First, we calculate the odds of labor market re-entry after forced turnover for each CEO in the sample using coefficients from the logistic regressions in Panel A of Table 6. This provides a measure of the ex ante probability that each CEO will find a new job if he were dismissed from his current position. We then estimate regressions of our innovation variables on the estimated odds of labor market re-entry while controlling for our standard covariates of corporate innovation. We present results of this analysis in Table 7.

\section{TABLE 7}

Corporate Innovation and the Probability of Labor Market Re-Entry

The dependent variables are the ratio of research and development (R\&D) expenditures to total assets in the first column and the natural logs of 1 plus patents applications eventually granted and citations per patent in the second and third columns, respectively. Re-entry odds using the three connection types is the natural log of the odds ratio for labor market re-entry following forced chief executive officer (CEO) turnover calculated using estimated parameters from the three models in Panel A of Table 6. Each regression includes the control variables in Table 2 as well as year and Fama-French (1997) 48 industry dummies. These variables are not reported to conserve space. Test statistics based on robust standard errors clustered at the CEO level are shown in parentheses. ${ }^{\star \star \star}$ and ${ }^{\star \star}$ indicate significance at the $1 \%$ and $5 \%$ levels, respectively.

\begin{tabular}{|c|c|c|c|c|c|c|c|c|c|}
\hline \multirow[b]{2}{*}{ Variables } & \multicolumn{3}{|c|}{$\begin{array}{c}\text { Panel A. } \\
\text { Re-Entry Odds Based on } \\
\text { CEO Connections }\end{array}$} & \multicolumn{3}{|c|}{$\begin{array}{l}\text { Panel B. } \\
\text { Re-Entry Odds Based on } \\
\text { Combined CEO Network }\end{array}$} & \multicolumn{3}{|c|}{$\begin{array}{c}\text { Panel C. } \\
\text { Re-Entry Odds Based on } \\
\text { Firms in CEO Network }\end{array}$} \\
\hline & R\&D & Patents & $\begin{array}{l}\text { Patent } \\
\text { Cites } \\
\end{array}$ & R\&D & Patents & $\begin{array}{l}\text { Patent } \\
\text { Cites } \\
\end{array}$ & R\&D & Patents & $\begin{array}{l}\text { Patent } \\
\text { Cites } \\
\end{array}$ \\
\hline $\begin{array}{l}\text { Re-entry odds } \\
\quad \text { (CEO connections) }\end{array}$ & $\begin{array}{l}0.006^{\star \star \star} \\
(4.37)\end{array}$ & $\begin{array}{l}0.166^{\star \star \star} \\
(3.10)\end{array}$ & $\begin{array}{l}0.106^{\star \star} \\
(2.25)\end{array}$ & - & - & - & - & - & - \\
\hline $\begin{array}{l}\text { Re-entry odds } \\
\text { (combined CEO network) }\end{array}$ & - & - & - & $\begin{array}{l}0.010^{* \star \star} \\
(6.53)\end{array}$ & $\begin{array}{l}0.225^{\star \star \star} \\
(3.79)\end{array}$ & $\begin{array}{l}0.167^{* \star *} \\
(2.99)\end{array}$ & - & - & - \\
\hline $\begin{array}{l}\text { Re-entry odds } \\
\quad \text { (firms in CEO network) }\end{array}$ & - & - & - & - & - & - & $\begin{array}{l}0.011^{\star \star \star} \\
(6.61)\end{array}$ & $\begin{array}{l}0.191^{* \star *} \\
(2.94)\end{array}$ & $\begin{array}{l}0.132^{\star *} \\
(2.23)\end{array}$ \\
\hline Pseudo $R^{2}$ & N.A. & 0.294 & 0.277 & N.A. & 0.294 & 0.277 & N.A. & 0.293 & 0.277 \\
\hline No. of obs. & 9,352 & 8,479 & 8,415 & 9,352 & 8,479 & 8,415 & 9,352 & 8,479 & 8,415 \\
\hline
\end{tabular}

In Panel A of Table 7, the odds of labor market re-entry are based on the number of individuals in the CEO's direct network. The result is positive and significant at the $1 \%$ level in the $R \& D$ and patent regressions and at the $5 \%$ level in the patent citations model. The coefficients imply that the change in the likelihood of post-dismissal employment associated with a movement from the first quartile to the third quartile in $\mathrm{CEO}$ connections increases $\mathrm{R} \& \mathrm{D}$ investment rate, patents, and citations per patent by $10 \%, 11 \%$, and $4 \%$, respectively. We obtain similar results in Panels B and C, where the odds of labor market re-entry are estimated based on the combined networks of the CEO's direct contacts and the number of firms with which the CEO is connected, respectively. Thus, CEOs who are more likely to obtain another top-level position in the event of an involuntary turnover invest more in corporate innovation. Based on these findings, we conclude that another important channel through which CEO connections encourage investment in risky innovation is by attenuating the personal consequences of a job loss. ${ }^{13}$

\footnotetext{
${ }^{13}$ Although the results presented in this section are based on detrended CEO connections, it is plausible that the more relevant measure of connections for labor market purposes is the actual number of contacts rather than the detrended variable. As a robustness check, we repeat all the tests in this
} 
Overall, the results in this section indicate that better-connected CEOs innovate more because personal connections provide at least two important benefits that ameliorate their risk aversion by reducing the riskiness of investing in explorative ideas. First, personal connections allow easier access to information that enhances the CEO's ability to identify, characterize, and evaluate innovation projects before investing in such projects as well as while the project is ongoing. Second, personal connections offer implicit labor market insurance that mitigates the career concerns inherent in risky innovation by enhancing the prospect for re-employment following job displacement. These two effects appear to enable better-connected CEOs to engage in significantly higher levels of corporate innovation.

\section{Summary and Conclusions}

As a firm's chief strategist and principal change agent, the CEO sets the tone for both the level and quality of corporate innovation activities. He also faces significant personal consequences depending on the outcome of such innovation. When innovation succeeds, he usually benefits from greater prestige and higher compensation. Conversely, he may endure public ridicule and adversarial relationships with other stakeholders (e.g., employees) when corporate innovation fails. Because failure is more likely with high-risk, high-return innovation than with routine and/or incremental projects, risk-averse CEOs are naturally predisposed to investing in the latter rather than the former.

We focus on the role of personal connections in ameliorating this risk aversion and fostering corporate innovation. We propose two arguments for this hypothesized effect. First, personal connections allow the CEO to access network information that enhances his ability to identify, evaluate, and execute innovation projects. This reduces the risk of failure on an ex ante basis. Second, personal connections provide implicit labor market insurance to the CEO by facilitating re-employment following a potential job loss. We test our hypothesis on a sample of almost 2,400 CEOs employed at over 1,500 firms during 1997-2006. We find that better-connected CEOs engage in more and higher quality innovation. They invest more in R\&D and are granted more patents by the USPTO. Those patents also attract more citations. Further tests support our hypothesis that these effects derive from the propensity of personal connections to provide the CEO with access to relevant network information and implicit labor market insurance.

Prior research suggests that the personal networks of executives impose agency costs on shareholders via excessive compensation, reduce pay-performance sensitivity, and lower performance-induced turnover rates. Our results indicate that there are some desirable facets of these connections. By providing a labor market hedge and access to relevant network information, personal connections help the CEO overcome his aversion to investing in risky innovation. We hope these results will motivate additional research into the impact of CEO connections

section using the natural $\log$ of actual CEO connections. We obtain results that are very similar to those reported in Tables 6 and 7. We do not present these results here but they are available from the authors. We thank an anonymous referee for suggesting this additional robustness check. 
on real firm activities with a view to providing a more complete understanding of the effects of such connections.

\section{Appendix. Variable Definitions}

CEO connections: Natural log of 1 plus the detrended number of individuals with whom the CEO shares a common educational, employment, or social history in BoardEx excluding those individuals connected to him solely via his position as CEO of his own firm.

Combined CEO network: Natural log of 1 plus the detrended number of individuals with whom the $\mathrm{CEO}$ is connected through his direct contacts.

Firms in CEO network: Natural log of 1 plus the detrended number of unique firms with which the CEO is connected through his direct contacts.

$R \& D$ : Ratio of research and development expenditures to total assets.

Patents: Natural log of 1 plus the number of patent applications filed during the year that were eventually granted.

Patent Cites: Natural log of 1 plus the average number of citations per patents, excluding citations in patents awarded to the same firm.

Firm size: Natural log of total assets in millions of dollars.

Market/book ratio: Book value of total assets minus the book value of equity plus the market value of equity, divided by the book value of total assets.

Classified board: 1 if directors are elected to staggered terms, and 0 otherwise.

ROA: Income before extraordinary items divided by total assets.

Tobin's q: Market value of common equity plus the book values of preferred equity and long-term debt divided by the book value of assets.

Capital expenditures: Ratio of capital expenditures to total assets.

Leverage: Ratio of long-term debt (including current portion) to total assets.

$C E O$ age: Natural log of the CEO's age measured in years.

CEO tenure: Natural log of the number of years for which the CEO has been in office.

CEO delta: $10^{-6}$ times the dollar sensitivity of CEO firm-specific wealth (option and stockholdings) to $1 \%$ change in the firm's stock price.

CEO vega: $10^{-6}$ times the dollar sensitivity of CEO firm-specific wealth (option and stockholdings) to 0.01 change in the firm's stock return volatility.

Golden parachute: 1 if the corporation has a golden parachute arrangement in place for the $\mathrm{CEO}$, and 0 otherwise.

CEO-chair: 1 if the $\mathrm{CEO}$ also serves as board chair, and 0 otherwise.

Founder CEO: 1 if BoardEx identifies the CEO as a founder or cofounder of the company.

Professional connections: Natural log of 1 plus the detrended number of individuals with whom the CEO shares a common employment history in BoardEx.

Education connections: Natural log of 1 plus the detrended number of individuals with whom the CEO attended the same school, graduated within 2 years of each other, and earned a similar type of degree. Degrees are similar if they are classified into the same category from the following six: i) doctorate, ii) medical, iii) law, iv) MBA (graduate business), v) other graduate, and vi) undergraduate. See Cohen, Frazzini, and Malloy (2008) for additional details.

Social connections: Natural log of 1 plus the detrended number of individuals with whom the CEO is connected through social clubs, charities, sporting, or other not-for-profit organizations. 
Connections from oldest job: Natural log of 1 plus the number of connections from the CEO's first position reported in BoardEx.

Latent ability index: 1 if the CEO attended an undergraduate program at a university or college with consistently high (top 20) SAT/ACT scores or secured his first executivelevel position before age 35 or won a professional recognition award at any point in his career or outperformed the industry median ROA during each of the 3 preceding years, and 0 otherwise.

Innovation ability: 1 if the firm received more patents than the median firm during each of the 3 preceding years of the CEO's tenure, and 0 otherwise.

Connections per employer: Natural log of 1 plus average CEO connections per previous employer.

Maximum connections: Natural log of 1 plus the number of connections from the previous position that provided the $\mathrm{CEO}$ with the most contacts.

Innovating connections: Fraction of each CEO's total contacts that are affiliated with innovative firms, that is, those with positive R\&D investment.

$R \& D$ connections: Predicted value from regressing CEO connections on the percentage of firms in the CEO's network that have positive R\&D expenditures.

Non- $R \& D$ connections: Residual from regressing CEO connections on the percentage of firms in the CEO's network that have positive R\&D expenditures.

\section{References}

Ang, J. S.; G. L. Nagel; and J. Yang. "The Effect of Social Pressures on CEO Compensation.” Working Paper, Florida State University (2010).

Atanassov, J. "Do Hostile Takeovers Stifle Innovation? Evidence from Antitakeover Legislation and Corporate Patenting." Journal of Finance, 68 (2013), 1097-1131.

Bhagat, S., and I. Welch. "Corporate Research and Development Investments: International Comparisons." Journal of Accounting and Economics, 19 (1995), 443-470.

Brown, J. R.; S. M. Fazzari; and B. C. Petersen. "Financing Innovation and Growth: Cash Flow, External Equity and the 1990s R\&D Boom." Journal of Finance, 64 (2009), 151-185.

Burt, R. S. "Structural Holes and Good Ideas." American Journal of Sociology, 110 (2004), 349-399.

Bushee, B. "The Influence of Institutional Investors on Myopic R\&D Investment Behavior." Accounting Review, 73 (1998), 305-333.

Chan, S. H.; J. D. Martin; and J. W. Kensinger. "Corporate Research and Development Expenditures and Share Value." Journal of Financial Economics, 26 (1990), 255-276.

Cheng, S. "Board Size and the Variability of Corporate Performance." Journal of Financial Economics, 87 (2008), 157-176.

Cingano, F., and A. Rosolia. "People I Know: Job Search and Social Networks." Journal of Labor Economics, 30 (2012), 291-332.

Cohen, L.; A. Frazzini; and C. Malloy. "The Small World of Investing: Board Connections and Mutual Fund Returns.” Journal of Political Economy, 116 (2008), 951-979.

Eberhart, A. C.; W. F. Maxwell; and A. R. Siddique. "An Examination of Long-Term Abnormal Stock Returns and Operating Performance Following R\&D Increases.” Journal of Finance, 59 (2004), 623-650.

Faleye, O. "Classified Boards, Firm Value, and Managerial Entrenchment." Journal of Financial Economics, 83 (2007), 501-529.

Faleye, O. "Classified Boards, Stability, and Strategic Risk Taking." Financial Analysts Journal, 65 (2009), 54-65.

Faleye, O.; R. Hoitash; and U. Hoitash. "The Costs of Intense Board Monitoring.” Journal of Financial Economics, 101 (2011), 160-181.

Fama, E. F., and K. R. French. "Industry Costs of Equity.” Journal of Financial Economics, 43 (1997), 153-193.

Fracassi, C., and G. Tate. "External Networking and Internal Firm Governance.” Journal of Finance, 67 (2012), 153-194.

Francis, B.; I. Hasan; and Z. Sharma. "Incentives and Innovation: Evidence from CEO Compensation Contracts." Working Paper, Rensselaer Polytechnic Institute (2011).

Granovetter, M. Getting a Job: A Study of Contacts and Careers. Cambridge, MA: Harvard University Press (1974). 
Griliches, Z. "Productivity, R\&D, and Basic Research at the Firm Level in the 1970s." American Economic Review, 76 (1986), 141-154.

Hall, B.; A. Jaffe; and M. Trajtenberg. "The NBER Patent Citations Data File: Lessons, Insights and Methodological Tools.” Working Paper, National Bureau of Economic Research (2001).

Hall, B., and R. Ziedonis. "The Determinants of Patenting in the U.S. Semiconductor Industry, 1980-1994." RAND Journal of Economics, 32 (2001), 101-128.

Harhoff, D.; F. Narain; F. M. Scherer; and K. Vopel. "Citation Frequency and the Value of Patented Inventions." Review of Economics and Statistics, 81 (1999), 511-515.

Hwang, B., and S. Kim. "It Pays to Have Friends." Journal of Financial Economics, 93 (2009), $138-158$.

Jensen, M. C. "The Modern Industrial Revolution, Exit, and the Failure of Internal Control Systems." Journal of Finance, 48 (1993), 831-880.

Kale, J.; E. Reis; and A. Venkateswaran. "Rank Order Tournaments and Incentive Alignment: The Effect on Firm Performance.” Journal of Finance, 64 (2009), 1479-1513.

Kothari, S. P.; T. E. Laguerre; and A. J. Leone. "Capitalization versus Expensing: Evidence on the Uncertainty of Future Earnings from Capital Expenditures versus R\&D Outlays." Review of Accounting Studies, 7 (2002), 355-382.

Kramarz, F., and D. Thesmar. "Social Networks in the Boardroom." Working Paper, Centre for Economic Policy Research (2007).

Larcker, D. F.; E. C. So; and C. C. Y. Wang. "Boardroom Centrality and Firm Performance." Journal of Accounting and Economics, 55 (2013), 225-250.

Manso, G. "Motivating Innovation.” Journal of Finance, 66 (2011), 1823-1860.

Mazerolle, M. J., and G. Singh. "Economic and Social Correlates of Re-Employment following Job Displacement." American Journal of Economics and Sociology, 63 (2004), 717-730.

McDonald, M. L.; P. Khanna; and J. D. Westphal. "Getting Them to Think Outside the Circle: Corporate Governance, CEOs' External Advice Networks, and Firm Performance.” Academy of Management Journal, 51 (2008), 453-475.

Puri, M., and D. T. Robinson. "The Economic Psychology of Entrepreneurship and Family Business." Journal of Economics and Management Strategy, 22 (2013), 423-444.

Sapra, H.; A. Subramanian; and K. Subramanian. "Corporate Governance and Innovation: Theory and Evidence.” Journal of Financial and Quantitative Analysis, 49 (2014), 957-1003.

Schonlau, R. J., and P. V. Singh. "Board Networks and Merger Performance.” Working Paper, Brigham Young University (2009).

Sougiannis, T. "The Accounting Based Valuation of Corporate R\&D.” Accounting Review, 69 (1994), 44-68.

Trajtenberg, M. "A Penny for Your Quotes: Patent Citations and the Value of Innovations." RAND Journal of Economics, 21 (1990), 172-187. 